\title{
Komunikasi Terapeutik Tenaga Medis tentang Obat Tradisional bagi Masyarakat
}

\author{
Ditha Prasanti \\ Prodi Ilmu Komunikasi, Universitas Padjadjaran, Jl. Raya Jatinangor -Sumedang KM 21 Bandung \\ E-mail: dithaprasanti@gmail.com
}

\begin{abstract}
Abstrak. Kesehatan merupakan hal yang sangat penting dijaga dalam kehidupan manusia. Jika individu mengalami sakit maka individu tersebut akan mencari pengobatan untuk menyembuhkan penyakitnya. Jenis komunikasi inilah yang disebut komunikasi terapeutik. Di era digital ini, peneliti menemukan adanya tenaga medis yang menggunakan obat tradisional untuk masyarakat. Obat tradisional bukanlah hal yang asing lagi bagi sebagian masyarakat di Indonesia. Obat tradisional juga memiliki kedudukan yang khusus dalam masyarakat, yakni sebagai warisan budaya lokal dalam bidang kesehatan. Pada era ini, obat tradisional pun masih digunakan oleh masyarakat baik sebagai alternatif utama maupun pilihan dalam pengobatan penyakit yang dialaminya. Peneliti tertarik untuk mengangkat penelitian tentang komunikasi terapeutik tenaga medis dalam pemberian informasi tentang obat tradisional bagi masyarakat. Di sinilah letak keunikan penelitian ini. Tenaga medis yang bekerja dalam dunia kesehatan, tetapi mengakui keampuhan obat tradisional dan memberikan informasi tersebut kepada masyarakat sebagai media penyembuhan. Peneliti menggunakan pendekatan kualitatif dengan studi kasus. Hasil penelitian tentang komunikasi terapeutik tenaga medis dalam pemberian informasi tentang obat tradisional bagi masyarakat ini meliputi : fase pra interaksi; fase orientasi; fase kerja komunikasi terapeutik; dan fase terminasi. Metode komunikasi terapeutik yang berlangsung pun dengan mengutamakan efektivitas hubungan antarpribadi antara tenaga medis dengan masyarakat yang menggunakan obat tradisional tersebut, yaitu: mendengarkan, mengulang, dan memberikan saran.
\end{abstract}

Kata kunci: komunikasi, terapeutik, tenaga medis, obat tradisional

\begin{abstract}
Health is a very important thing to be maintain in human life. If the individual experiences pain then the individual will seek treatment to cure his illness. This type of communication is called therapeutic communication. In this digital era, researchers found the existence of medical personnel who use traditional medicine for the community. Traditional medicine is not a strange thing for some people in Indonesia. Traditional medicine also has a special position in society, namely as a local cultural heritage in the field of health. In this era, traditional medicine is still used by the community both as the main alternative and choice in the treatment of the disease they experienced. In this study, researchers interested in raising research on therapeutic communications of medical personnel in the use of traditional medicine for people in the digital era. Herein lies the uniqueness of this research. Medical workers who work in the health field, but recognize the efficacy of traditional medicine and recommend it to the community as a healing medium. Researchers used a qualitative approach with case studies. The results of research on Therapeutic Communication of Medical Personnel in the Provision of Information on Traditional Medicines for Communities in this digital era include: pre-interaction phase; Orientation phase; Therapeutic communication working phase; And termination phases. Therapeutic communication methods that take place with the priority of the effectiveness of interpersonal relationships between medical personnel and the people who use these traditional drugs, are: listening; repeat, and provide suggestions.
\end{abstract}

Keywords: communication, therapeutic, medical personnel, traditional medicine 


\section{PENDAHULUAN}

$\begin{array}{ccr}\text { Setiap individu } & \text { saling } \\ \text { berkomunikasi } & \text { untuk } & \text { memenuhi } \\ \text { kebutuhan hidupnya, baik } & \text { kebutuhan }\end{array}$ primer, sekunder, maupun tersier. Kesehatan merupakan hal yang termasuk dalam kebutuhan primer bagi manusia. Siapa pun pasti menginginkan hidup sehat lahir dan batin. Jika manusia mengalami sakit, maka dia akan berupaya mencari pengobatan untuk menyembuhkan penyakitnya tersebut. Dalam hal ini, terjadilah komunikasi terapeutik antara tenaga medis, baik dokter, perawat, bidan, dengan pasiennya.

Komunikasi yang efektif dalam kegiatan konsultasi dokter dan pasien akan memengaruhi kesembuhan pasien. Komunikasi yang direncanakan secara sadar, bertujuan, dan kegiatannya dipusatkan untuk kesembuhan pasien disebut sebagai komunikasi terapeutik (Taufik, 2010:25). Komunikasi terapeutik sangat penting dan berguna bagi pasien, karena komunikasi yang baik dapat memberikan pengertian tingkah laku pasien dan membantu pasien dalam mengatasi persoalan yang dihadapinya (Utami: 2015).

Pengobatan tradisional masih banyak digunakan sebagai alternatif dalam masyarakat, hal ini menjadi bukti bahwa masyarakat masih mengakui khasiat dari pengobatan tradisional, dengan demikian jenis-jenis tanaman yang dapat dijadikan obat harus tetap dilestarikan dan dijaga agar dapat dimanfaatkan sebagai resepresep tradisional warisan orang tua terdahulu dalam upaya menunjang pelayanan kesehatan (Wijayakusuma \& Dalimartha: 2001).

Pemerintah secara formal sudah memberikan perhatian yang saksama terhadap muncul dan berkembangnya pengobatan tradisional ini. Pengobatan tradisional dalam Undang-Undang RI No. 36 tahun 2009 tentang Kesehatan Pasal 1 butir 16 mengatakan bahwa
Pelayanan kesehatan tradisional adalah pengobatan dan atau perawatan dengan cara dan obat yang mengacu pada pengalaman dan keterampilan turuntemurun secara empiris yang dapat dipertanggungjawabkan dan diterapkan sesuai dengan norma yang berlaku di masyarakat (Sembiring \& Sismudjito, 2015: 35).

Indonesia sebagai produk budaya dari masyarakat setempat. Dalam kajian komunikasi kesehatan, obatobatan tradisional yang diproduksi oleh masyarakat yang ada di beberapa daerah di Indonesia itu sangat beragam. Masyarakat di suatu daerah tertentu memiliki obat tradisional yang berbeda dengan masyarakat dari daerah yang lain. Keanekaragaman hayati yang terdapat di lingkungan tempat mereka hidup serta kearifan lokal yang mereka miliki, menjadi salah satu penyebab munculnya bermacam-macam produk budaya dalam bentuk obat tradisional (Darmastuti, 2011:).

Beberapa contoh obat tradisional yang dimiliki oleh masyarakat Indonesia tersebut, misalnya kencur yang sering digunakan untuk mengobati sakit batuk. Kencur yang sudah dihancurkan, kemudian diambil airnya untuk diminum. Di beberapa daerah, masyarakat menggunakan daun jambu yang ditumbuk dan dihancurkan, kemudian diambil airnya untuk mengobati diare (Prasanti \& El Karimah, 2016: 368).

Pada era digital ini, hal yang menarik dalam penelitian ini adalah tenaga medis yang menggunakan pengobatan tradisional untuk masyarakat di daerah tertentu. Tenaga medis yang peneliti temukan ini memilih masyarakat di daerah-daerah, dengan alasan: (1) Masyarakat yang tinggal di daerah pedesaan masih memiliki kepercayaan yang kuat terhadap warisan budaya lokal seperti halnya menggunakan obat tradisional; (2) Masyarakat yang tinggal 
di daerah pedesaan juga memiliki akses yang sedikit dalam menjangkau pengobatan medis di rumah sakit modern di perkotaan; (3) Masyarakat yang tinggal di daerah pedesaan dapat memperoleh obat-obatan tradisional yang dimaksud dengan mudah karena kondisi alamnya yang subur sangat mendukung.

Sebagai tenaga medis yang bekerja secara profesional dalam bidang kesehatan, tetapi masih mengakui khasiat dari obat tradisional. Dalam hal ini, peneliti menemukan fenomena ini sebagai hal yang menarik untuk diteliti. Peneliti ingin mengangkat tentang komunikasi terapeutik tenaga medis dalam pemberian informasi tentang obat tradisional bagi masyarakat di era digital ini.

Berdasarkan latar belakang di atas, peneliti tertarik untuk mengangkat penelitian tentang komunikasi terapeutik tenaga medis dalam pemberian informasi tentang obat tradisional bagi masyarakat di era digital ini. Fenomena ini diteliti dengan menggunakan pendekatan kualitatif dan metode studi kasus. Adapun teknik pengumpulan data yang digunakan adalah observasi, wawancara mendalam, dan studi dokumentasi. Penelitian ini bertujuan untuk mengetahui: (1) Proses komunikasi terapeutik tenaga medis dalam pemberian informasi tentang obat tradisional bagi masyarakat; (2) metode komunikasi terapeutik yang digunakan tenaga medis dalam pemberian informasi tentang obat tradisional bagi masyarakat.

\section{Penggunaan obat tradisional}

Obattradisional dancarapengobatan tradisional yang dimiliki oleh masyarakat Indonesia mempunyai peranan yang sangat besar dari generasi yang satu ke generasi berikutnya. Penggunaan obat tradisional dan cara petengobatan tradisional ini terus digunakan secara turun-temurun dalam menyelesaikan permasalahan kesehatan mereka. Bahkan, pengunaan obat tradisional dan cara pengobatan tradisional ini tetap digunakan dan dilakukan pada zaman modern ini (Prasanti \& El Karimah, 2016: 369).

Setiap manusia pada dasarnya akan berusaha terhindar dari situasi sakit karena kondisi sakit akan mengakibatkan seseorang mengalami berbagai kendala dalam melakukan kegiatan sehari-hari. Kesehatan juga menjadi kebutuhan bagi setiap individu, baik orang yang sakit maupun yang sehat. Pada dasarnya, hal ini menjelaskan bahwa kesehatan adalah kebutuhan manusia dari berbagai kalangan baik dilihat dari sisi ekonomi, sosial, geografi, psikologi perkembangan, maupun status kesehatan. Orang yang sakit membutuhkan penyembuhan sedangkan orang sehat membutuhkan adanya peningkatan kesehatan dan pelayanan kesehatan yang optimal (Prasanti: 2017).

Seperti halnya di Indonesia, sebanyak 49,5\% atau setengah penduduk Indonesia masih menggunakan pengobatan tradisional berupa jamujamuan, 4,5\% di antaranya mengonsumsi obat tradisional setiap hari dan sisanya mengonsumsi sekali-sekali. Obat tradisional tersebut dapat berupa racikan sendiri, dari pengobat tradisional maupun buatan industri. Negara Indonesia memiliki kekayaan tersendiri dalam pengobatan tradisional, dari 30.000 spesies tumbuhan yang ada 7000 di antaranya merupakan tumbuhan yang dapat digunakan sebagai obat yang tersebar di seluruh daerah. Indonesia juga memiliki sekitar 280.000 orang praktisi pengobatan tradisional pada berbagai daerah (Sembiring \& Sismudjito, 2015:37).

Obat tradisional telah diterima secara luas di hampir seluruh negara di dunia. Menurut WHO, negara-negara di Afrika, Asia, dan Amerika Latin menggunakan obat herbal sebagai pelengkap pengobatan primeryang mereka terima. Bahkan, di Afrika, sebanyak 80\% 
dari populasi menggunakan obat herbal untuk pengobatan primer (WHO: 2003).

WHO merekomendasi penggunaan obat tradisional, termasuk herbal, dalam pemeliharaan kesehatan masyarakat, pencegahan, dan pengobatan penyakit, terutama untuk penyakit kronis, penyakit degeneratif, dan kanker. WHO juga mendukung upaya-upaya dalam peningkatan keamanan dan khasiat dari obat tradisional (WHO: 2003).

Penggunaan obat tradisional secara umum dinilai lebih aman dari pada penggunaan obat modern. Hal ini disebabkan karena obat tradisional memiliki efek samping yang relatif lebih sedikit dari pada obat modern. Selain itu, obat tradisional juga lebih murah jika dibandingkan dengan obat farmasi. Hal ini menyebabkan peranan obat tradisional di masyarakat, Indonesia khususnya, sangatlah penting dan dirasakan manfaatnya. Selalu mendapatkan kesehatan yang prima merupakan impian semua orang. Berbagai resep dengan memanfaatkan berbagai obat tradisional mungkin sudah sering didengar. Dengan memanfaatkan buah-buahan, daundaunan, atau hal lain yang umum dijumpai di dapur sebagai bumbu masak atau pelengkap masakan, ternyata dapat pula dimanfaatkan untuk mengatasi masalah kesehatan. Khasiatnya sudah dapat dibuktikan selama beberapa generasi (Lusia, 2006: 2).

\section{Komunikasi terapeutik}

Komunikasi terapeutik adalah komunikasi yang direncanakan secara sadar, bertujuan dan kegiatannya dipusatkan untuk kesembuhan pasien. Dalam dunia kesehatan, banyak kegiatan komunikasi terapeutik yang terjadi. Menurut Mulyana (2005) komunikasi terapeutik termasuk komunikasi interpersonal yaitu komunikasi antara orang-orang secara tatap muka yang memungkinkan setiap pesertanya menangkap reaksi orang lain sacara langsung, baik secara verbal dan nonverbal.

Menurut Heri Purwanto, komunikasi terapeutik adalah komunikasi yang direncanakan secara sadar dan bertujuan dan kegiatannya difokuskan untuk kesembuhan pasien, dan merupakan komunikasi professional yang mengarah pada tujuan untuk penyembuhan pasien (Mundakir, 2006).

Komunikasiterapeutikmeningkatkan pemahaman dan membantu terbentuknya hubungan yang konstruktif di antara perawat dengan klien. Tidak seperti komunikasi sosial, komunikasi terapeutik mempunyai tujuan untuk membantu klien mencapai suatu tujuan dalam asuhan keperawatan. Stuart dan Sundeen (Taufik, 2010:45) menjelaskan bahwa dalam prosesnya komunikasi terapeutik terbagi menjadi empat tahapan, yaitu tahap persiapan atau tahap pra-interaksi, tahap perkenalan atau orientasi, tahap kerja dan tahap terminasi.

\section{Tahap persiapan/pra-interaksi}

Pada tahap pra-interaksi, dokter sebagai komunikator yang melaksanakan komunikasi terapeutik mempersiapkan dirinya untuk bertemu dengan klien atau pasien. Sebelum bertemu pasien, dokter haruslah mengetahui beberapa informasi mengenai pasien, baik berupa nama, umur, jenis kelamin, keluhan penyakit, dan sebagainya. Apabila dokter telah dapat mempersiapkan diri dengan baik sebelum bertemu dengan pasien, maka ia akan bisa menyesuaikan cara yang paling tepat dalam menyampaikan komunikasi terapeutik kepada pasien, sehingga pasien dapat dengan nyaman berkonsultasi dengan dokter.

\section{Tahap perkenalan/orientasi}

Tahap perkenalan dilaksanakan setiap kali pertemuan dengan pasien dilakukan. Tujuan dalam tahap ini adalah 
memvalidasi keakuratan data dan rencana yang telah dibuat sesuai dengan keadaan pasien saat ini, serta mengevaluasi hasil tindakan yang telah lalu. Tahap perkenalan/orientasi adalah ketika dokter bertemu dengan pasien. Persiapan yang dilakukan dokter pada tahap prainteraksi diaplikasikan pada tahap ini. Sangat penting bagi dokter untuk melaksanakan tahapan ini dengan baik karena tahapan ini merupakan dasar bagi hubungan terapeutik antara dokter dan pasien.

\section{Tahap kerja}

Tahap kerja merupakan inti dari keseluruhan proses komunikasi terapeutik. Tahap kerja merupakan tahap yang terpanjang dalam komunikasi terapeutik karena di dalamnya dokter dituntut untuk membantu dan mendukung pasien untuk menyampaikan perasaan dan pikirannya dan kemudian menganalisis respons ataupun pesan komunikasi verbal dan nonverbal yang disampaikan oleh pasien. Dalam tahap ini pula dokter mendengarkan secara aktif dan dengan penuh perhatian sehingga mampu membantu pasien untuk mendefinisikan masalah yang sedang dihadapi oleh pasien, mencari penyelesaian masalah dan mengevaluasinya.

\section{Tahap terminasi}

Terminasi merupakan akhir dari pertemuan dokter dan pasien. Tahap terminasi dibagi dua, yaitu terminasi sementara dan terminasi akhir. Terminasi sementara adalah akhir dari tiap pertemuan dokter dan pasien, setelah hal ini dilakukan dokter dan pasien masih akan bertemu kembali pada waktu yang berbeda sesuai dengan kontrak waktu yang telah disepakati bersama. Sedangkan terminasi akhir dilakukan oleh dokter setelah menyelesaikan seluruh proses keperawatan.

Metode atau teknik yang digunakan dalam komunikasi terapeutik, antara lain, menurut Stuart dan Sundeen (Mundakir, 2006:131), yaitu mendengarkan (listening), pertanyaan terbuka (broad opening), mengulang (restoring), klarifikasi, refleksi, memfokuskan, membagi persepsi, identifikasi tema, diam (silence), pemberian informasi (informing), dan memberikan saran. Dengan melaksanakan beberapa teknik atau metode komunikasi terapeutik, maka kegiatan komunikasi terapeutik dapat dilaksanakan dengan baik. Pasien dapat dengan nyaman memberikan informasi yang dibutuhkan dokter untuk mengupayakan kesembuhan pasien, dan dokter pun dapat mempermudah pekerjaannya dalam menentukan tindakan apa yang harus dilakukan untuk mempercepat proses penyembuhan pasien. Semakin baik kerjasama yang dilakukan antara dokter dan pasien, maka semakin baik pula hasil yang dapat dicapai untuk mempercepat proses penyembuhan pada pasien.

\section{METODE}

Pendekatan penelitian yang peneliti gunakan dalam penelitian ini adalah pendekatan kualitatif dengan metode studi kasus. Mulyana (2005: 201) menyatakan bahwa "studi kasus merupakan uraian dan penjelasan komprehensif mengenai berbagai aspek seorang individu, suatu kelompok, atau organisasi (komunitas), suatu program, atau suatu situasi sosial". Penelitian studi kasus berupaya menelaah sebanyak mungkin data mengenai subjek yang diteliti. Dalam hal ini, data tersebut dimungkinkan didapatkan melalui wawancara mendalam, pengamatan, penelaahan dokumen hasil survei, dan data apa pun untuk menguraikan suatu kasus secara terperinci.

Menurut Yin (2002), studi kasus dapat dibagi ke dalam single-case dan multiple-case.

"Single-case digunakan jika kasus yang diteliti itu merupakan kasus yang 
ekstrim atau unik, memenuhi semua kondisi untuk menguji teori-teori yang ada, memiliki kesempatan untuk mengobservasi dan menganalisis fenomena yang sebelumnya tidak diselidiki secara ilmiah, sedangkan multiple-case memungkinkan dilakukannya perbandingan di antara beberapa kasus" (Yin, 2002: 46-48).

Dalam penelitian yang peneliti lakukan, peneliti menggunakan singlecase study design, karena tujuan penelitian ini adalah untuk memperoleh informasi menyeluruh secara detail dan pemahaman tentang komunikasi terapeutik tenaga medis dalam penggunaan obat tradisional bagi masyarakat di era digital.

Studi kasus, sebagai suatu metode kualitatif, mempunyai beberapa keuntungan. Menurut Lincoln dan Guba yang dikutip Mulyana (2005: 201), keistimewaan studi kasus meliputi halhal sebagai berikut:

(1) Merupakan sasaran utama bagi penelitian emik, yakni menyajikan pandangan subjek yang diteliti,

(2) menyajikan uraian menyeluruh mirip dengan apa yang dialami pembaca dalam kehidupan seharihari,

(3) merupakan sarana efektif untuk menunjukan hubungan antara peneliti dengan nara sumber,

(4) memungkinkan pembaca menemukan konsistensi internal yang terpercaya,

(5) memberikan "uraian tebal" yang diperlukan bagi penilaian atas transferabilitas,

(6) terbuka bagi penilaian atas konteks yang turut berperan bagi pemaknaan atas fenomena dalam konteks tersebut.

\section{Penentuan data dan sumber data}

Data yang ada dalam penelitian kualitatif bersifat empiris, terdiri atas dokumentasi ragam peristiwa, rekaman setiap ucapan, kata, dan gestures dari objek kajian, tingkah laku yang spesifik, dokumen-dokumen tertulis serta berbagai imaji visual yang ada dalam sebuah fenomena sosial. Untuk mendapatkan hasil analisis yang mendalam, maka diperlukan data dari setiap tahapan penelitian. Data yang diperlukan berasal dari data primer dan data sekunder (Mulyana: 2005).

Data primer diperoleh dari pihakpihak terkait langsung dengan penelitian yang terdiri dari:

(1) Hasil pengamatan atau observasi terhadap perilaku informan pada penelitian tentang komunikasi terapeutik tenaga medis dalam penggunaan obat tradisional

(2) Hasil wawancara langsung secara mendalam dari informan penelitian tentang komunikasi terapeutik tenaga medis dalam penggunaan obat tradisional

Data sekunder dapat mendukung ketajaman analisis penelitian. Data sekunder diperoleh dari rujukan khusus yang terdiri dari:

(1) Literatur. Orientasi melalui bacaan yakni dengan menelaah literaturliteratur yang berisi teori-teori, kerangka pikir, serta brosurbrosur yang berhubungan dengan topik yang diteliti, yaitu yang berhubungan dengan strategi komunikasi.

(2) Studi dokumentasi, hal ini untuk mendapatkan data-data sekunder yang digunakan untuk menunjang penelitian yang akan dilakukan.

\section{Teknik pengumpulan data}

Teknik pengumpulan data dalam penelitian kualitatif adalah dengan melakukan observasi, wawancara mendalam, dan studi dokumentasi.

(1) Observasi yang dilakukan dalam penelitian ini adalah pengamatan. Pengamatan dilakukan dengan 
cara nonparticipant observation, terhadap objek yang diteliti yaitu yang berkaitan dengan komunikasi terapeutik tenaga medis dalam penggunaan obat tradisional bagi masyarakat.

(2) Wawancara mendalam (Depth interview) yang dilakukan penulis dalam penelitian dimaksudkan untuk mengetahui pandangan, kejadian, kegiatan, pendapat, perasaan dari nara sumber (subjek matter expert). Wawancara yang dilakukan yaitu untuk mengetahui mengenai komunikasi terapeutik tenaga medis dalam penggunaan obat tradisional bagi masyarakat. Penggunaan teknik ini sangat penting bagi penelitian kualitatif, terutama untuk melengkapi data dan upaya memperoleh data yang akurat dan sumber data yang tepat.

(3) Studi Dokumentasi, menurut Burhan Bungin (2007: 121), metode dokumenter adalah metode yang digunakan untuk menelusuri data historis. Dokumentasi dalam penelitian ini diperlukan terutama untuk memperkaya landasanlandasan teoritis dan mempertajam analisis penelitian yang berkaitan komunikasi terapeutik tenaga medis dalam penggunaan obat tradisional bagi masyarakat. Dokumen yang dimaksud dapat berupa berita kegiatan internal, surat kabar, atau media massa lainnya.

\section{Teknik analisis data}

Burhan Bungin (2007: 253259) menyatakan bahwa penelitian kualitatif menghadapi persoalan penting mengenai pengujian keabsahan hasil penelitian. Banyak hasil penelitian kualitatif diragukan keabsahannya karena beberapa hal: (1) Subjektivitas peneliti; (2) Kelemahan-kelemahan metode wawancara; (3) Sumber data kualitatif yang kurang dapat dipercaya. Untuk mendapat keabsahan hasil penelitian tentang pemanfaatan media online egyptian cream, peneliti menggunakan teknik-teknik pemeriksaan keabsahaan sebagai berikut:

(1) Ketekunan pengamatan di lapangan yang penulis lakukan dimaksudkan untuk memperoleh derajat keabsahan yang tinggi. Pengamatan dilakukan secara nonparticipant, yaitu penulis melakukan mengamati kegiatan komunikasi tanpa ikut berperan serta.

(2) Trianggulasi yang penulis lakukan yaitu triangulasi sumber data, yaitu membandingkan data hasil pengamatan dengan data hasil wawancara.

(3) Pengecekan sejawat dilakukan melalui diskusi dengan berbagai kalangan yang memahami masalah penelitian. Pengecekan sejawat yang dilakukan dengan ahli medis.

(4) Kecukupan refensial dilakukan dengan memperbanyak referensi yang dapat menguji dan mengoreksi hasil penelitian yang dilakukan, baik referensi yang berasal dari orang lain maupun referensi yang diperoleh selama penelitian.

\section{Informan penelitian}

Dalam penelitian ini, peneliti menggunakan teknik purposive sampling, yakni memilih informan sesuai dengan kebutuhan peneliti. Jadi, peneliti mengambil tiga informan yaitu: (1) Rn, tenaga medis dokter; (2) Rs, tenaga medis perawat; (3) St, dosen Ilmu Keperawatan.

\section{TEMUAN PENELITIAN}

Berdasarkan hasil observasi dan wawancara yang peneliti lakukan, peneliti menghasilkan temuan yang menarik tentang penelitian. Temuan ini tentu dapat memperkaya penelitian tentang Komunikasi Terapeutik Tenaga Medis 
dalam pemberian informasi tentang Obat Tradisional Bagi Masyarakat. Peneliti menjabarkan temuan ini dalam beberapa point di bawah ini.

\section{Proses komunikasi terapeutik tenaga medis}

Dalam penelitian ini, proses komunikasi terapeutik tenaga medis dalam penggunaan obat tradisional bagi masyarakat meliputi tahapan sebagai berikut:

\section{Pada fase prainteraksi/tahap persiapan}

$\mathrm{Rn}$, informan penelitian ini adalah tenaga medis yang konsisten dengan obat tradisional. Rn melanjutkan studi tentang obat herbal di Universitas Indonesia. Dalam proses komunikasi terapeutik yang dialaminya dengan pasien, $\mathrm{Rn}$ melakukan fase pertama yaitu fase pra interaksi, disebut juga tahap persiapan. Dalam tahap ini, Rn menceritakan tentang khasiat obat tradisional yang telah teruji secara klinis kepada masyarakat di daerah-daerah. Pada tahap persiapan ini, Rn memberikan informasi sejelasjelasnya kepada masyarakat agar mereka semakin paham bahwa penggunaan obat tradisional harus sesuai dengan kandungannya, ada evidence based-nya, tidak bisa sembarangan, khawatir ada efek samping atau penyalahgunaan dalam obat tradisional tersebut.

Rs, sebagai informan kedua dalam penelitian ini, juga menceritakan hal yang sama, proses komunikasi terapeutik yang dilakukannya diawali dengan tahap persiapan, yaitu memberikan informasi yang akurat dan jelas kepada masyarakat tentang kandungan dan khasiat dari obat tradisional tersebut. Hal ini dilakukan dengan tujuan agar masyarakat memahami dengan benar tentang penggunaan obat tradisional yang perlu diketahui telah teruji secara klinis.

St, dosen Ilmu Keperawatan ini juga menegaskan hal yang sama tentang pentingnya evidence based dari obat tradisional tersebut. Hal ini juga harus disampaikan terlebih dahulu kepada masyarakat agar tidak terjadi kesalahan persepsi dalam menggunakan obat tradisional yang sembarangan. Ini juga dilakukan sebagai langkah awal dalam proses komunikasi seorang tenaga medis kepada pasiennya, khususnya yang mengakui tentang khasiat dari obat tradisional.

\section{Pada fase orientasi.}

Proseskomunikasi terapeutik tenaga medis dalam penggunaan obat tradisional bagi masyarakat di daerah, tahap kedua ini disebut fase orientasi atau pengenalan. Dalam tahap ini, tenaga medis melakukan perkenalan dengan masyarakat, antara lain memberikan salam kepada pasien, memperkenalkan diri, menanyakan nama klien, memulai percakapan awal dengan pasien, menanyakan keluhan utama pasien.

Pernyataan tersebut juga disampaikan oleh ketiga informan dalam penelitian ini. $\mathrm{Rn}$ menceritakan ketika dia melakukan proses komunikasi dengan pasiennya, tahap kedua setelah memberikan informasi adalah fase orientasi. Dalam fase ini, tenaga medis berperan sebagai komunikator yang kredibel, baik dokter, perawat, maupun bidan. Rs juga menjelaskan bahwa dalam tahap ini, sebagai tenaga medis, mereka perlu melaksanakan tiga ciri sikap dalam komunikasi terapeutik yaitu: genuineness (keikhlasan), empathy (empati), dan Warmth (kehangatan) agar tahap awal komunikasi terapeutik berjalan secara efektif.

Menurut St, sebagai dosen Ilmu Keperawatan, menyampaikan hal yang sama dalam proses komunikasi terapeutik ini. Sebaiknya para tenaga medis melalui tahapan ini agar pasien atau masyarakat yang meminta informasi tentang pengobatannya dapat mengerti 
dengan baik. Fase orientasi ini tentu harus dilakukan oleh tenaga medis dengan mengutamakan ciri dalam komunikasi terapeutik, yaitu keikhlasan, empati, dan kehangatan. Kondisi ini akan membuat masyarakat atau pasien mudah menerima informasi yang disampaikan oleh tenaga medis. Hal ini jugalah yang biasa dilakukan informan, Rn dan Rs, sebagai tenaga medis yang selalu mempraktekkan ciri komunikasi terapeutik ini dalam melayani pasiennya.

\section{Pada fase kerja}

Komunikasi terapeutik tenaga medis dalam pemberian informasi tentang obat tradisional bagi masyarakat di daerah-daerah, juga dilakukan dengan fase kerja. Pada fase ini, Rn dan Rs sebagai tenaga medis melaksanakan beberapa metode komunikasi terapeutik seperti; mendengarkan, mengulang, dan memberikan saran. Hal ini disampaikan dalam bagian metode komunikasi terapeutik. Selain itu, para informan juga memperhatikan komunikasi verbal yang ditunjukkan pasien ketika berkonsultasi dengan dokter atau tenaga medis lainnya. Hal ini dilakukan karena pada tahap ini, dokter harus memiliki banyak informasi mengenai pasien, sehingga dokter dapat memberikan pengobatan yang tepat kepada pasien.

Contoh lain adalah pada era digital ini, ada juga dokter yang berani secara terbuka mengakui khasiat obat tradisional, Dr.Boyke Dian Nugraha, DpOG, MARS, ginekolog dan konsultan sex dari Rumah Sakit Kanker Dharmais, Jakarta (Dalam Koran Tempo, 23 Maret 2001), mengemukakan bahwa keunggulan bahan-bahan alami adalah aman dipakai, tanpa efek samping. "Makanya saya selalu ingin mengobati pasien saya dengan bahan-bahan alami”. Menurutnya terlalu banyak mengkonsumsi obat-obatan yang mengandung bahan kimia berisiko terkena penyakit, seperti kanker. Sejak dulu ia dan keluarganya selalu berusaha mengobati penyakit dengan bahan-bahan alami. Bahan alami (dalam bentuk food supplement) yang biasanya diresepkan Boyke antara lain madu, lidah buaya dan mengkudu (Atep Afia, 2011).

\section{Pada tahap terminasi}

Fase ini adalah fase terakhir dalam proses komunikasi terapeutik. Para informan penelitian ini menggunakan tahap terminasi dengan cara menyimpulkan hasil konsultasi pasien dengan dirinya. $\mathrm{Rn}$ dan Rs mengaku bahwa pada tahap ini, kegiatan konsultasi yang dilakukan pasien dan dokter akan menghasilkan kesimpulan mengenai penyakit yang diderita pasien, penyebabnya, dan obat yang tepat bagi penyakit tersebut. Sebagai tenaga medis yang mendalami tentang khasiat obat tradisional, Rn dan Rs menyimpulkan tentang khasiat dari obat tradisional yang dimaksud dapat menyembuhkan penyakit pasiennya. Selain itu, para informan juga memberikan nasehat. Pada tahap ini, nasehat tersebut bisa berupa pantangan dan anjuran yang harus dilakukan pasien ketika berada di rumah.

\section{Metode Komunikasi Terapeutik}

$\mathrm{Rn}$ menceritakan bahwa dia menggunakan metode komunikasi terapeutik, yaitu mendengarkan; mengulang; dan memberikan saran. Metode inilah yang efektif dalam proses komunikasi terapeutik yang biasa dilakukannya, khususnya dalam pemberian informasi tentang obat tradisional. Menurut Rn, sebagian besar masyarakat modern tidak percaya pada khasiat dari obat tradisional. Ada juga pasien yang tidak mau karena mereka tidak menyukai rasa dari obat tradisional. Rn menceritakan bahwa hal ini bukan berarti dia meninggalkan obat-obatan kimiawi, karena menurutnya jenis obatobatan ini tentu menyesuaikan pada 
kepercayaan dari pasien atau masyarakat tersebut.

$\mathrm{Rn}$ sendiri adalah tenaga medis yang menggunakan obat tradisional untuk dirinya dan keluarganya. Hal inilah yang membuat dirinya juga melanjutkan studi tentang obat herbal di salah satu perguruan tinggi negeri di Jakarta. Rn selalu mendengarkan keluhan rasa sakit yang dirasakan oleh masyarakatnya, khususnya pemberian informasi tentang obat tradisional ini dia berikan kepada masyarakat di daerah-daerah, karena mereka masih memegang kepercayaan dan tradisi dari leluhur dalam menggunakan obat-obatan tradisional. Setelah mendengarkan pasiennya, Rn baru menjelaskan khasiat dari obat tradisional yang telah teruji secara klinis dan sesuai dengan jenis penyakit yang diderita oleh pasiennya. Rn mengulang kembali apa yang dirasakan oleh pasiennya, lalu memberikan saran kepada pasiennya berkaitan dengan jenis obat-obatan yang dianjurkan, serta nasehat lainnya.

Begitupun halnya dengan Rs dan St, mereka juga sepakat bahwa metode komunikasi terapeutik yang paling sesuai digunakan dalam pemberian informasi tentang obat tradisional ini adalah mendengarkan, mengulang, dan memberikan saran kepada pasiennya.

\section{PEMBAHASAN}

Teori komunikasi yang relevan dengan penelitian ini adalah teori interaksi simbolik. Interaksi simbolik ada karena ide-ide dasar dalam membentuk makna yang berasal dari pikiran manusia (mind) mengenai diri (self), dan hubungannya di tengah interaksi sosial, dan tujuan akhir untuk memediasi, serta menginterpretasi makna di tengah masyarakat (society) dimana individu tersebut menetap. mind, self and society merupakan judul buku yang menjadi rujukan utama teori interaksi simbolik, merefleksikan tiga konsep utama dari teori. Definisi singkat dari ketiga ide dasar dari interaksi simbolik, yaitu:

(1) Pikiran (mind). Pikiran adalah kemampuan untuk menggunakan simbol yang mempunyai makna sosial yang sama, dimana tiap individu harus mengembangkan pikiran mereka melalui interaksi dengan individu lain (West dan Turner, 2007: 102). Simbol yang bermakna adalah tindakan verbal berupa bahasa yang merupakan mekanisme utama interaksi manusia. Penggunaan bahasa atau isyarat simbolik oleh manusia dalam interaksi sosial mereka pada gilirannya memunculkan pikiran (mind) yang memungkinkannya menginternalisasi masyarakat. Jadi menurut Mead, pikiran mensyaratkan adanya masyarakat; dengan kata lain masyarakat harus lebih dulu ada sebelum adanya pikiran (West dan Turner, 2007: 102).

(2) Diri (self). Diri adalah kemampuan untuk merefleksikan diri sendiri dari sudut pandang atau pendapat orang lain. Di sini diri tidak dapat dilihat dari dalam diri seseorang melalui introspeksi diri. Bagi Mead, diri hanya bisa berkembang melalui kemampuan pengambilan peran, yaitu membayangkan diri dari pandangan orang lain (West dan Turner, 2007 : 103). Konsep melihat diri dari pandangan orang lain sebenarnya sebuah konsep yang pernah disampaikan oleh Charles Cooley pada 1912. Konsepnya adalah the looking glass self, yaitu kemampuan melihat diri melalui pantulan dari pandangan orang lain. Cooley meyakini bahwa ada tida prinsip perkembangan sehubungan dengan the looking glass self, yaitu (1) membayangkan penampilan kita di hadapan orang lain, (2) 
membayangkan penilaian mereka terhadap penampilan kita, dan (3) merasa sakit hati atau bangga karena perasaan diri.

(3) Masyarakat (society) adalah jejaring hubungan sosial yang diciptakan, dibangun, dan dikonstruksikan oleh tiap individu ditengah masyarakat, dan tiap individu tersebut terlibat dalam perilaku yang mereka pilih secara aktif dan sukarela, yang pada akhirnya mengantarkan manusia dalam proses pengambilan peran di tengah masyarakatnya. Oleh karena itu masyarakat terdiri atas individu-individu yang terbagi ke dalam dua bagian masyarakat yang mempengaruhi pikiran dan diri.

Berdasarkan pemaparan tentang latar belakang pemikiran besar tentang manusia yang memengaruhi pemikiran George Herbert Mead dan konsep dasar dari interaksi simbolik, maka dapat disimpukan bahwa terdapat tiga tema konsep interaksi simbolik, yaitu :

(1) Pentingnya makna bagi perilaku manusia. Dalam penelitian ini, peneliti melihat adanya pengakuan dari informan tentang pentingnya pemberian informasi kepada pasien, khususnya yang tinggal di daerah, mengenai obat tradisional sebagai media penyembuhan dalam proses komunikasi terapeutik.

(2) Pentingnya konsep mengenai diri, peneliti juga melihat bahwa para informan mengangap pentingnya konsep mengenai diri, dalam hal ini adalah proses komunikasi terapeutik yang terdiri atas empat tahap, yaitu tahap prainteraksi; tahap orientasi; tahap kerja; dan tahap terminasi. Proses komunikasi terapeutik ini dilakukan dalam memberikan informasi tentang obat tradisional.

(3) Hubungan antara individu dengan masyarakat. Teori interaksi simbolik berperan dalam menjelaskan tentang kerangka referensi untuk memahami bagaimana manusia, bersama dengan orang lain, menciptakan dunia simbolik, dan bagaimana cara dunia membentuk perilaku manusia ini, memberikan pemahaman tentang khasiat dari obat tradisional yang telah teruji secara klinis.

Konsep dasar dari interaksi simbolik merupakan makna, makna dalam penelitian ini tercipta karena hubungan yang terjadi di antara individu dengan masyarakatnya, dalam kasus ini, makna yang diciptakan oleh tenaga medis akan dipahami sesuai dengan masyarakat lingkungan setempat. Hal ini menyebabkan makna yang terbentuk tentang komunikasi terapeutik tenaga medis juga memengaruhi cara, pola pikir, dan perilaku yang berlaku dalam mayarakat pedesaan tersebut.

\section{SIMPULAN}

Hasil penelitian tentang "Komunikasi Terapeutik Tenaga Medis dalam Penggunaan Obat Tradisional bagi Masyarakat" di era digital ini meliputi: fase prainteraksi; fase orientasi; fase kerja komunikasi terapeutik; dan fase terminasi. Metode komunikasi terapeutik yang berlangsung pun dengan mengutamakan efektivitas hubungan antarpribadi antara tenaga medis dengan masyarakat yang menggunakan obat tradisional tersebut, yaitu mendengarkan; mengulang; dan memberikan saran. Pada prinsipnya, komunikasi terapeutik tenaga medis dalam hal pemberian informasi tentang obat tradisional ini, sebaiknya dilakukan pada obat tradisional yang telah ada evidence based-nya, teruji khasiatnya. Hal ini juga untuk menghindari terjadinya kesalahan dalam menggunakan obat tradisional. 


\section{DAFTAR PUSTAKA}

Atep Afia Hidayat. (2011). Peran Obat Tradisional Makin Menguat, diakses dari http://www.kompasiana.com pada 19 Maret 2017.

Bungin, Burhan. (2007). Penelitian Kualitatif. Jakarta: Kencana Prenada Media Group.

Cresswell, John W. (1998). Research Design, Qualitative \& Quantitative Approaches. Yogyakarta: Pustaka Pelajar.

Damaiyanti, Mukhripah. (2010). Komunikasi Terapeutik dalam Praktik Keperawatan. Bandung: Refika Aditama.

Ditha Prasanti. (2017). Peran Obat Tradisional dalam Komunikasi Terapeutik Keluarga. Jurnal Komunikasi Universitas Garut Vol.3 No.1, 2017.

Dyana Utamy. (2015). Komunikasi Terapeutik Dokter Dan Pasien Dalam Pengobatan Homeopati Di Pusat Pengobatan Al Jawad Pekanbaru. Jurnal Jom FISIP Vol. 2 No. 1 - Februari 2015. Empowerment. Yogyakarta: Buku Litera.

Yin, Robert.K. (2002). Studi Kasus (Desain dan Metode). Jakarta. PT. Raja Grafindo Persada.

Lusia Oktora Ruma Kumala Sari., (2006). Pemanfaatan Obat Tradisional Dengan Pertimbangan Manfaat Dan Keamanannya, Majalah Ilmu Kefarmasian, Vol. III, No.1, April 2006.

Mulyana, Deddy. (2005). Metodologi Penelitian Komunikasi. Bandung: Remaja Rosda Karya.

Mundakir. (2006). Komunikasi Keperawatan: Aplikasidalam Pelayanan, Yogyakarta, Graha Ilmu.
Prasanti, Ditha \& Kismiyati El Karimah. (2016). Chapter of Book. Media, Communication, and Society

Rakhmat, Jalaludin. (2002). Metode Penelitian Komunikasi. Bandung : PT Remaja Rosdakarya.

Rini Darmastuti dan Dewi Kartika Sari. (2011). Kekuatan Kearifan Lokal dalam Komunikasi Kesehatan. Jurnal KOMUNIKATOR, Vol. 3, No. 2, November 2011.

Salmen Sembiring dan Sismudjito. (2015). Pengetahuan dan Pemanfaatan Metode Pengobatan Tradisional Pada Masyarakat Desa Sukanalu Kecamatan Barus Jahe. Jurnal Perspektif Sosiologi, Vol.3 No.1, Oktober 2015.

Sugiyono. (2007). Metode Penelitian Kuantitatif, Kuantitatif dan $R \& D$. Bandung: Alfabeta.

Sukandar, E. (2006). Neurologi Klinik. Edisi ketiga. Bandung: Pusat Informasi Ilmiah (PII) Bagian Ilmu Penyakit Dalam Fakultas Kedokteran UNPAD.

Susenas. (2007). Microdata.bps.go.id, diakses pada 10 Februari 2017.

Taufik M \& Juliane. (2010). Komunikasi Terapeutik dan Konseling dalam Praktek Kebidanan. Jakarta: Salemba Medika.

West, Richard. Lynn H.Turner. (2007). Pengantar Teori Komunikasi. Jakarta: Salemba Humanika.

Wijayakusuma, H., dan Dalimartha. (2001). Ramuan Tradisional untuk Pengobatan Darah Tinggi. Jakarta: Penebar Swadaya.

World Health Organization. (2003). Schistosomiasis and soil transmitted helminths country profile: Indonesia. http://www.who.int/wormcontrol/ databank/Indonesia_ncp3.pdf, diakses pada 20 Maret 2017. 